\title{
The Effect of Precipitation on Sediment Transport at Batang Padang River, Perak
}

\author{
Nurul Farehah Amat ${ }^{1, a}$, Mohd Shalahuddin Adnan ${ }^{1, b}$, Zawani Mohd Zahudi ${ }^{1, \mathrm{c}}$, \\ Yuliarahmadila Erfen ${ }^{1, \mathrm{~d}}$, Noorfathiah Che Ali ${ }^{1, \mathrm{e}}$ \\ ${ }^{1}$ Department of Water and Environmental Engineering \\ Universiti Tun Hussein Onn Malaysia, 86400 Batu Pahat, Johor Darul Takzim, Malaysia. \\ anurulfarehahamat@gmail.com, bmohdshalahuddin@gmail.com, wanizahudi88@gmail.com, \\ dyuliaerfen@gmail.com, ${ }^{\mathrm{e}}$ fathiazu@gmail.com
}

Keywords: Rainfall, sediment transport, correlation grade.

\begin{abstract}
Study of sediment management is important to ensure the sedimentation process that occurred can be properly managed. Sediment have a positive correlation with the precipitation where, if the amount of precipitation is high then the sediment transport rate also will be increase. The additional of sediment into the river will shallow the river and lead to flooding. Thus, this analysis is carried out on the Batang Padang River to prove that there is a positive reaction by the precipitation and the amount of sediment, and will affect river management. The precipitation and sediment data from 1982 to 1996 were retrieved from Department of Irrigation and Drainage (DID) data base. Statistical analysis using the methods of correlation was used to determine the relationship between two variable has been prescribed. Based on the analyzed data, the highest value of rainfall was $3832.5 \mathrm{~mm}$ in 1988, and the highest value of sediment is 15331.9 tonnes/year was accured in 1985. Grade correlation is between 0:51 to 0.94 for observations fifteen years. Where the average grade of correlation that has been analyzed is 0.7 . The results of the data analysis clearly shows that precipitation has a significant relationship with sediment.
\end{abstract}

\section{Introduction}

River is one of the physical components of the earth, and frequently get the attention of researchers because our earth is experiencing severe environmental degradation due to human activities. Soil erosion, flooding and increased sediment is a serious environmental problem facing in the world and become a threat to economic development, agricultural enterprises and community development.

Sediment is a natural substance that is broken down by processes of weathering and erosion further transported by the action of wind, water and gravity. The presence of sediment in the river can cause pollution of water resources, filling dams and may have an impact on aquatic habitats [1]. Logically, the deposition will reduce the storage reservoirs in the watershed. Sedimentation process also causing river is become shallow, and may continue to disappear. Effects, flash floods and severe floods will occur in the river mouth [2]. Sediments also occur due to the amount of erosion from the hills and slopes [3]. Sediment production is closely related to climate and hydrological factors in a catchment area and it became a big issue that needs to be emphasized.

This paper is based on monthly rainfall data taken from the Sungai Manik, Teluk intan river station and sediment data collected from the Batang Padang river, Teluk Intan river station. Data was analyzed from the years 1982 - 1996 for 15 years of data to correlate rainfall effects on sediment accretion. The aim of this study is to investigate the extent to which the precipitation will affect the amount of sediment produced in the catchment area and to prove that it will give a positive response in which they are interrelated. This study just focus on making the correlation from year 1982-1996 to see the relationship variables.Input from the analysis is important in the management of rivers and water resources, particularly for domestic use, hydrology and agriculture, especially the paddy cultivation. 


\section{Study area}

Studies have been carried out on the Batang Padang River at Teluk Intan, Perak. Batang Padang district area is 52,836 hectares and have 34200 population that is mostly farmers and ranchers. Batang Padang River located at longitude 101 095414 "E , $4^{\circ} 026669$ "N and the area of the catchment is $121.9 \mathrm{~km}^{2}$. Batang Padang River is flowing from Cameron highland in Pahang state and merged with Bidor River and subsequently merged with the Perak River. Batang Padang River is very important to supply the water for irrigation in agricultural areas.

\section{Methodology}

\section{Data collection}

Data used for the study of the effect of precipitation on sediment transport is taken from the Department of Irrigation and Drainage that is located in Ampang, Kuala Lumpur where all the data associated with the river which is the water levels, rainfall, sediment, evaporation and water discharge are obtained from that department . Nevertheless, only the sediment data and rainfall data is needed in the study. Sediment data collected from the Sungai Manik,Teluk Intan station and rainfall data taken at Sungai Batang Padang,Teluk intan stations. The data taken is 15 years from 1982 until 1996.

\section{Statistical analysis}

In the case of this study, the correlation method is used to obtain the relationship between two variables, namely the amount of rainfall and the amount of sediment. Correlation is a statistical measure that indicates the extent to which two or more variables fluctuate together. Correlation is positive when the values increase together, and correlation is negative when one value decreases as the other increases.

In this correlation relationship, the value of a variable is very important to measure the correlation between the variable. When the correlation value is obtained from $0-0.3$, it shows that the correlation between the two variables is low positive correlation, if the correlation value obtained is from 0.3-0.8, it shows the relationship between two variables is a high positive correlation, whereas when the correlation approaching 1 in the 0.8-1.0, it shows the relationship between two variables is perfect positive correlation.

After the correlation is done, it will show whether the correlation is highly correlated or no correlation. When the relationship is closer to the value of 1 , it indicates that the relationship between these variables are highly related and when the value is approaching to 0 or negative values, it shown that the relationship between these variables is not consistent or do not relate to each other.

\section{Result and discussion}

Data for 15-year where there is in year 1982 to 1996 taken from two stations for both variable for the study. Sediment data are collected from Sungai Manik, Teluk Intan station and rainfall data collected from Sungai Batang Padang, Teluk Intan station. Both stations are taken from the Teluk Intan to avoid error in data occurred.

Graph for the amount of the sediment and precipitation made for showing how variable studied both increases and decreases in parallel and if the graphs that have been studied is not parallel between the two variable, the causes studied to find out why the rise and fall of the graph occurs. 


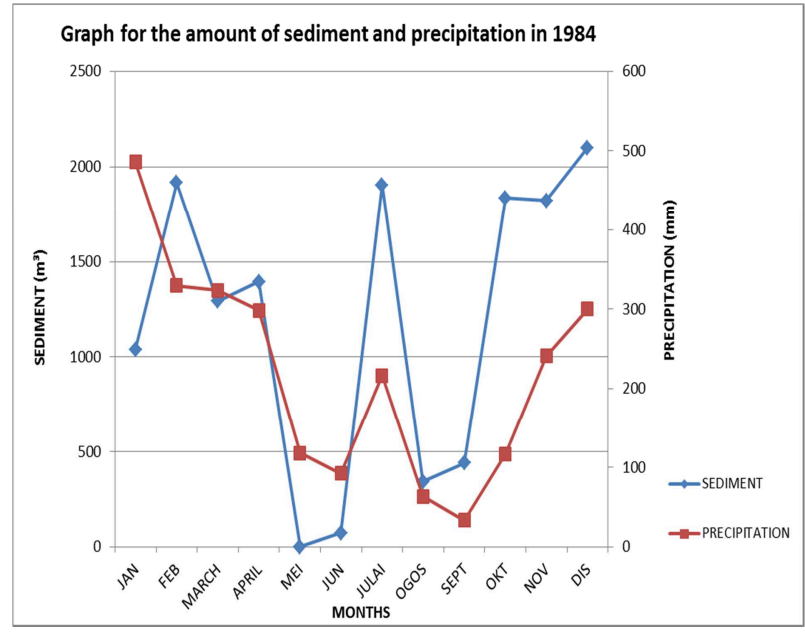

(a)

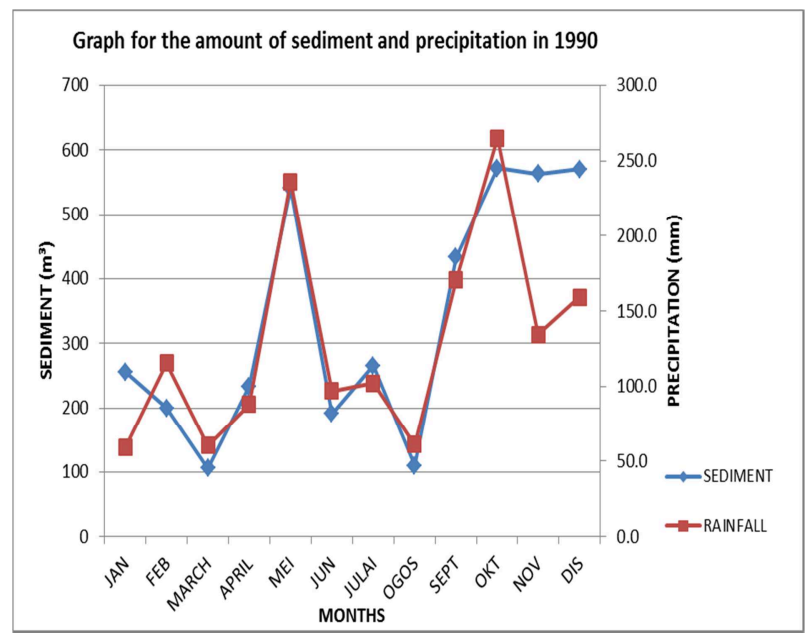

(c)

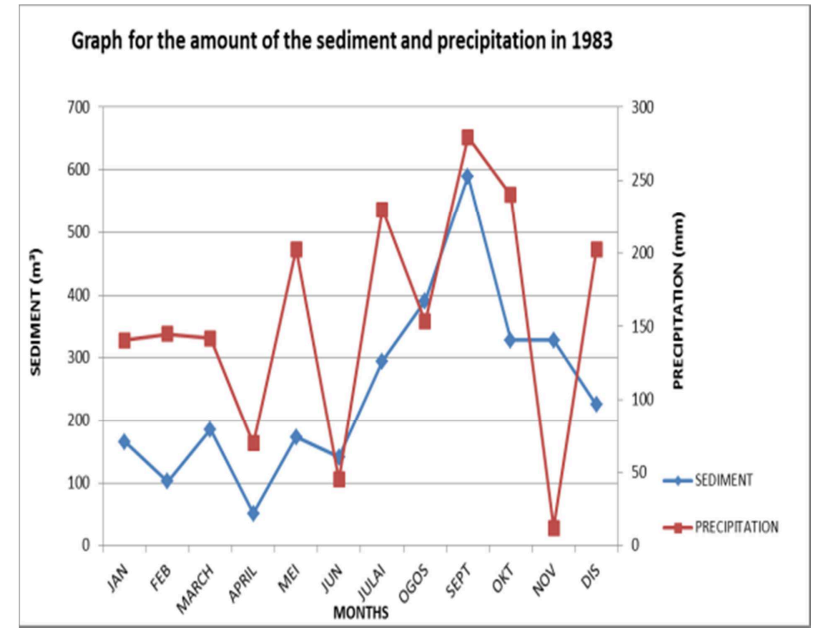

(b)

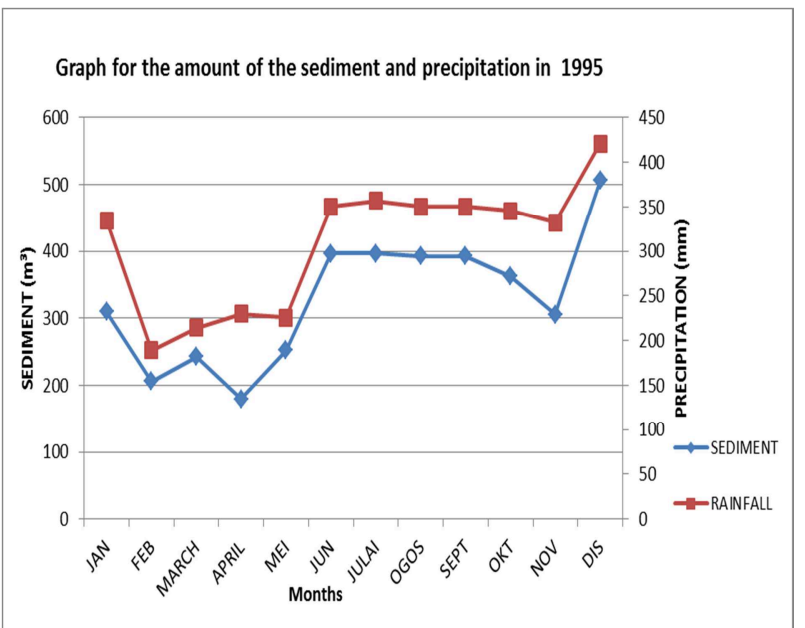

(d)

Fig 1, The amount of sediment and precipitation for the several year ni year 1982-1986.

The fig 1(a) from the 1984 and observed in every month. The graph is found that in January, February, March, April, June and September showed that the two variables do not move in parallel. This graph instability also occurs in the river in 2003 because there is a lot happening river bank erosion, river pollution and the degradation of water resources [4]. This is probable occur in Batang Padang River.

The fig 1(b) from the 1983 and observed in every month. The graph shows that in February, august, November and December do not move in parallel. This shows that there are several factors that cause the graph obtained not move in parallel. In February and December showed that when the rain increased, the sediment is decreased. This shows that during the month, an improvement on the river have been done such as maintaining a layer of protection on the land, build the retaining special agents of erosion such as wind, rain, and change the landscape to control the number and average erosion.

The fig 1(b) from the 1983 and observed in every month. Graph shows that in January, the number of sediment and the amount of rainfall does not show the same increase. This is because in January even though the amount of rainfall decreases, the sediment still increase. It happened because in that year, there has been severe erosion and there is no recovery on the river bank [5].

The figure 1(d) from the 1995 and observed in every month. On the graph found that every month the amount of rainfall played a role in the increasing the amount of sediment in the river. 
Graph also shows that when the precipitation are in large quantities, the amount of sediment will increase parallel with the amount of precipitation. The graph shows that the relationship between the amount of precipitation and the amount of sediment is closely related. Precipitation affect the amount of sediment produced.

\section{Correlation analysis of the sediment and precipitation variables}

Correlation analysis of rainfall and the amount of sediment using 15 years of data provided by DID was obtained with a average grade correlation 0.7. Based on the objectives of the study, using the correlation method is the most effective way to examine whether these variables are closely interrelated or not directly related. The analysis shows that in 15 years, the correlation value calculated is in the range 0.51 to 0.94 . This shows that it has a high positive correlation.

Table 1, Table shows the correlation between the amount of rainfall and the amount of sediment

\begin{tabular}{lrrrrrrrr}
\hline YEAR & 1982 & 1983 & 1984 & 1985 & 1986 & 1987 & 1988 & 1989 \\
CORRELATION & 0.573 & 0.517 & 0.506 & 0.822 & 0.691 & 0.814 & 0.747 & 0.541 \\
& & & & & & & & \\
\hline YEAR & 1990 & 1991 & 1992 & 1993 & 1994 & 1995 & 1996 & \\
CORRELATION & 0.837 & 0.714 & 0.592 & 0.569 & 0.57 & 0.936 & 0.737 &
\end{tabular}

$\underline{\text { Average Correlation }=0.7}$

\section{Conclusion}

There are 141 days receiving rainfall within 7 days $50-100 \mathrm{~mm}$ and has reached more than $100 \mathrm{~mm}$ of rain per day. In the 15 years of data taken, the amount of the highest daily rainfall was reached up to $153.5 \mathrm{~mm}$. The amount of sediment produced during the 15 years is in the range from 2 thousand to 16 thousand tons per year. The number is very large and can cause flooding occurs because when the amount of sediment too much, it will cause the river became shallow and will cause water overflow. According to a report from the JPS [6], the flood situation in Teluk Intan is largely due to the overflow of water from the Batang Padang River. This overflow is caused by the river can not accommodate a lot of water and it is also due to the shallow river due to erosion that occurs. This erosion occurs mostly due to the river currents speed and cause riverbank erosion happen and indirectly it will affect the earth changes. In conclusion, rainfall and sediment related with each other and it has been proved by the method of correlation which obtained a positive correlation grade of 0.7 where it approaches 1.0. Therefore, the authorities must make an effective solution to the problems associated with the sediment can be avoided.

\section{Acknowledgement}

First of all, the author gratefully acknowledges the financial support provided by University of Tun Hussein Onn Malaysia (UTHM) Johor, Malaysia under Grant FRGS 1232. Thanks also to the organizers, Universiti Tun Hussein Onn Malaysia for hosting this conference for all researchers to share their research and also to supervisor, DR. Mohd Shalahuddin Bin Adnan as assist in the writing and presentation of important knowledge to develop productive work. Finally, thank you to family and friends who have helped in this study directly or indirectly. 


\section{References}

[1] SR. Sisakht, B. Majnounian, E. Abdi, Impact of rainfall intensity and cutslope material on sediment concentration from forest roads in northern Iran, vol. 7, pp. 48-52, 2014.

[2] M. E. Toriman, M.K.A. Kamarudin, N.A.A. Aziz, Pengurusan sedimen terhadap sumber air bersepadu: Satu kajian kes di Sungai Chini, Pekan. Pahang, vol. 7, number 1, pp. 267-283, 2012.

[3] F. Damian, Cross-drain Placement to Reduce Sediment Delivery from Forest Roads to Streams , Master Thesis, University of Washington, 2003.

[4] S.F.M. Sani, Analisis Karakteristik Lapisan Endapan dan Hubunganya dengan Kandungan Nutrient di dalam Tanih Satu Kajian Kes Dataran Banjir Sungai Muda: Kedah, Universiti Sains Malaysia, 2012.

[5] C.F. Kun, Impact of land use change on hydroelectric power generation in Cameron Highland, Master Research, Malaya University, 2002.

[6] Laporan kemajuan dan status perlaksanaan, JPS Hilir Perak, 2012. 